\title{
Student's thinking to identify concave plane based on Gregorc model
}

\author{
Surya Enjang Krisdiantoro, Erlina Prihatnani ${ }^{1}$
}

\begin{abstract}
Abstrak: Pembelajaran matematika seharusnya memfasilitasi siswa membangun pengetahuan sendiri. Dalam membangun pengetahuan, siswa melibatkan beragam proses dan gaya berpikir. Penelitian kualitatif ini bertujuan untuk mendeskripsikan proses berpikir siswa dalam mengidentifikasi bangun datar concave berdasarkan gaya berpikir model Gregorc. Subjek penelitian adalah 33 siswa kelas IX SMP yang memiliki gaya berpikir berbeda. Data dikumpulkan melalui tes, angket, dan wawancara non-terstruktur kemudian dianalisis secara deskriptif untuk mengungkap gaya dan proses berpikir siswa. Penelitian ini menemukan dua gaya berpikir berbeda yaitu Sekuensial Konkret dan Acak Abstrak dari siswa yang berhasil mengidentifikasi bangun datar concave sebagai layang-layang. Terdapat perbedaan proses berpikir dalam pembentukan pengertian, pembentukan pendapat, dan penarikan kesimpulan dari siswa dengan gaya berpikir berbeda. Namun demikan, perbedaan gaya berpikir dari setiap proses berpikir tidak membatasi keberhasilan siswa dalam mengkonstruksi suatu pengetahuan.
\end{abstract}

Kata kunci: Proses berpikir, Gaya berpikir, Bangun concave, Model Gregorc

\begin{abstract}
Mathematics learning should facilitate students' construction of knowledge. In constructing mathematics knowledge, students involve various types of thinking processes and styles. This qualitative research aimed to describe the process of students' thinking in identifying concave plane based on Gregorc's model of thinking style. It involved thirty-three $9^{\text {th }}$-grade students with a different style of thinking. Data were collected through tests, questionnaire, and non-structured interview then descriptively analyzed to reveal students' thinking process and styles. The present study found two different thinking styles, namely Sequential Concrete and Random Abstract from students who successfully identified the concave plane as a kite. There were different thinking processes in the development of definition, opinion, and conclusions from subjects with different thinking styles. However, the difference in the thinking process from each thinking styles do not hamper students' success in constructing knowledge.
\end{abstract}

Keywords: Thinking process, Concave place, Thinking style, Gregorc model

\section{A. Introduction}

Thinking is students' mental activity of constructing knowledge by manipulating or processing information into memory to relate existing knowledge to prior knowledge with specific goals (Suryabrata, 2002; Santrock, 2007; Purwanto, 2013). The process or stages of thinking are called the thinking process (Suryabrata, 2002). Santrock (2007) accounts that thinking process includes the activities of forming concepts, reasoning, and thinking critically to make a decision or solve a problem. Correspondingly, Suryabrata (2002) divides the process

\footnotetext{
${ }^{1}$ Department of Mathematics Education Universitas Kristen Satya Wacana, Jln. Diponegoro 52-60, Salatiga, Indonesia, suryakris49@gmail.com
} 
of thinking into three stages: (1) the formation of definition, a process of analyzing the characteristics of similar objects; (2) the formation of an opinion, a process of seeing the relationship between two or more definitions, (3) conclusion, a result of analysing existing opinions. In this case, the differences in the thinking process are caused by different ways person process information in developing concepts, reasoning, and drawing conclusions. The differences in processing information is called thinking style (Gregorc, 1982).

Gregorc (1982) explains two possible brain dominations that affect one's thinking style, namely (1) concrete or abstract perception, and (2) sequential (linear) or random (nonlinear). Concrete perception is a person's ability to identify real objects. In contrast, abstract perception is a person's ability to identify abstract things, through imagination, without seeing a reality. The ability to arrange sequentially or linear is to regulate things in order which is in line with the directions. On the other hand, the ability to arrange randomly or non-linear is to manage things that are sometimes not in accordance with the rules, jumping around, and tend to follow one's own desires. Indeed, Gregorc (1982) combines the possibility of brain dominance into four thinking styles, namely Sequential Concrete, Sequential Abstract, Random Concrete, and Random Abstract.

Prior studies (e.g., Masfingatin, 2014; Yanti \& Syazali, 2016; Suryadinata \& Farida, 2016) have examined students' thinking processes. Masfingatin (2014) found the differences in thinking processes from the high, medium, and low achieved students in the formation of definition, opinion, and conclusions in solving solid problems. Yanti and Syazali (2016) concluded in their study that students with different types of adversity quotient have different thinking processes in solving mathematical problems.

There are also several studies (e.g. Myers \& Dyer, 2006; Zakir, 2015; Setyawan, 2017; Sahatcija, Ora, \& Ferhataj, 2017; Djadir, Upu, \& Sulfianti, 2018) which specifically refer to Gregorc's (1982) model of thinking. Myers and Dyer (2006) found that students with deeply embedded Sequential Abstract learning style preferences exhibited significantly higher critical thinking. Zakir (2015) found differences in students' logical thinking based on Gregorc's (1982) model of thinking in solving mathematical problems. Setyawan (2017) showed the different processes of constructing knowledge between random concrete and random abstract students, but it did not affect their success in doing construction. Sahatcija et al. (2017) revealed that thinking style only had an impact on achievement and not on the perception of learning methods. Furthermore, Djadir et al. (2018) concluded students who have thinking styles based on Gregorc have distinct profiles in solving mathematical problems.

Geometry is important schools mathematics topics for students (Gunhan, Turgut, \& Yilmaz, 2009; Aydogdu \& Kesan, 2014). However, students still experienced difficulties in understanding geometry (e.g., Mutia, 2017; Misnasanti \& Mahmudi, 2018). The cognitive domain index of Indonesian students in geometry is still classified as Low International Benchmark (TIMSS, 2015). Not only Indonesian students, but several studies (e.g. Özerem, 2012; Biber, Tuna, \& Korkmaz, 2013) also showed students' misconceptions in geometry in other countries. Thus, further studies to understand and improve the teaching and learning of geometry should have much greater attention, including understanding students' thinking process which refers to their thinking styles when working with geometrical objects in school mathematics. Clearly, each student has a different thinking process, even when she/he is faced with the same problem (Mustaqim \& Wahib, 2010; Lussier \& Hendon, 2017). By knowing students' thinking processes, the teachers will be able to design efficient learning models 
(Ramadhan, 2017) which help students construct their mathematical knowledge and problemsolving ability.

The present study addressed the importance of understanding students' thinking processes which refer to their thinking styles in identifying geometrical objects. Specifically, it aimed at analyzing the process of students' thinking (Suryabrata, 2002) who correctly identified a concave plane based on Gregorc's model of thinking style. This study chiefly differs from aforementioned relevant prior studies which firstly determine students' thinking styles then analyse variables which relate to it, for instance, critical thinking (Myers \& Dyer, 2006) or logical thinking (Zakir, 2015) and achievement (Sahatcija et al., 2017) since it identified students' thinking styles through their stages of thinking process in developing definition, forming opinion, and drawing conclusion then the identified thinking styles were confirmed through questionnaire. Thus, the current study provided students' thinking processes which characterize their thinking styles. Obviously, the description of students' thinking can be used as a pivotal entry point to design mathematics learning.

\section{B. Methods}

This study employed qualitative approach (Creswell \& Creswell, 2014) which divided into two stages: the selection of subjects who could identify concave plane and the analysis of thinking process and thinking styles from the selected subject. The procedure of study embedded with data analysis are explained below.

Firstly, non-routine (Figure 1) test was given to 33 ninth-grade students. It aimed to reveal students' thinking process in constructing a new concept (concave plane) using prior knowledge. The use of concave plane, which is not formally introduced in the school geometry (MoEC, 2016) enable students' thinking process- not just memorization of a learned-concept. The test was validated by experts and declared to be feasible and valid as instruments to explore students' thinking styles in their thinking processes when identifying the concave plane. Secondly, ten correct answers were selected from all students' works on the test. Then, it was carefully checked regarding the clarity and uniqueness, which result in 2 answers. Thus, two students were selected as the subjects and clinically interviewed (Zazkis \& Hazzan, 1998) to disclose their thinking styles through the thinking process in identifying the concave plane. We developed an evaluation matrix (Table 1) to help analyze the interview data. Thirdly, after revealing possible thinking styles with its description of the thinking process, the subjects were given Le Tellier's thinking style questionnaire (DePorter \& Hernacki, 2016) to confirm identified thinking styles in the interview.

Table 1. Matrix of thinking process and styles in identifying the concave plane

\begin{tabular}{|c|c|c|}
\hline \multirow{2}{*}{$\begin{array}{c}\text { Thinking processes and } \\
\text { indicators } \\
\text { (Suryabrata, 2002) }\end{array}$} & \multicolumn{2}{|c|}{$\begin{array}{c}\text { Thinking styles and indicators } \\
\text { (Gregorc, 1982) }\end{array}$} \\
\hline & Sequential concrete & Random abstract \\
\hline Establishing a definition & & \\
\hline $\begin{array}{l}\text { 1. Analyzing the characteristics } \\
\text { of similar objects } \\
\text { 2. Compare the characteristics } \\
\text { 3. Abstracting }\end{array}$ & $\begin{array}{l}\text { a. Sequential and structured } \\
\text { b. Based on the visible reality }\end{array}$ & $\begin{array}{l}\text { a. Unstructured } \\
\text { b. Tend to do what is desired } \\
\text { c. Based on existing theories } \\
\text { or concepts }\end{array}$ \\
\hline
\end{tabular}

Making opinion

1. Positive opinion

a. Hold on to reality

a. Absorb ideas and

2. Negative opinion information and arrange 


\begin{tabular}{|c|c|c|}
\hline \multirow{2}{*}{$\begin{array}{c}\text { Thinking processes and } \\
\text { indicators } \\
\text { (Suryabrata, 2002) } \\
\end{array}$} & \multicolumn{2}{|c|}{$\begin{array}{c}\text { Thinking styles and indicators } \\
\text { (Gregorc, 1982) }\end{array}$} \\
\hline & Sequential concrete & Random abstract \\
\hline 3. Opinion of modality & $\begin{array}{l}\text { b. Based on the reality that can } \\
\text { be directly observed } \\
\text { c. Look at something in detail } \\
\text { d. Hard to imagine } \\
\text { e. Linear processing }\end{array}$ & $\begin{array}{l}\text { them in the form of } \\
\text { reflection } \\
\text { b. Time is not a priority } \\
\text { c. Easy to imagine } \\
\text { d. Difficult to argue under } \\
\text { limited circumstances }\end{array}$ \\
\hline \multicolumn{3}{|l|}{ Drawing conclusion } \\
\hline $\begin{array}{l}\text { 1. Inductive } \\
\text { 2. Deductive } \\
\text { 3. Analogical }\end{array}$ & $\begin{array}{l}\text { a. Able to draw conclusions } \\
\text { deductively or inductively } \\
\text { b. In accordance with standard } \\
\text { stages and procedures }\end{array}$ & $\begin{array}{l}\text { a. Draw conclusions } \\
\text { analogically } \\
\text { b. Need to look holistically } \\
\text { before giving conclusions } \\
\text { c. Conclude in his own way }\end{array}$ \\
\hline
\end{tabular}

1. Take a look at the figure!

a. Analyze the plane and determine its type!

b. Guess the type of plane in 5 chances and provide an explanation for your guess!

c. Sort your answers from what you think is the most correct!

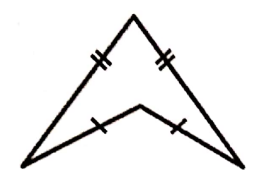

d. Write your answer in the given space!

2. Considering the properties of the plane below, which plane is most similar to a plane on number 1 ? Give your reason!

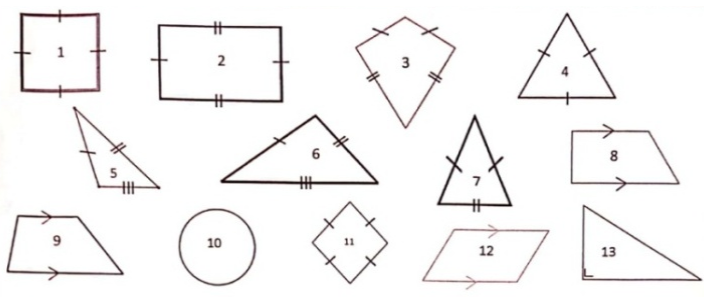

Figure 1. Two non-routine problems to identify the concave plane

\section{Findings and Discussion}

The concave plane in the test has similar properties to a kite. Although students had studied kite since elementary school, it is convex type as shown in Figure 2. Therefore, it is not surprising that there was only one student who could classify the concave plane as a kite in the first answer or guess, while other 32 students identified it as a triangle even though it is clear that the shape has four sides. Students' responses on the first answer to problem number 1 can be seen in Graph 1.

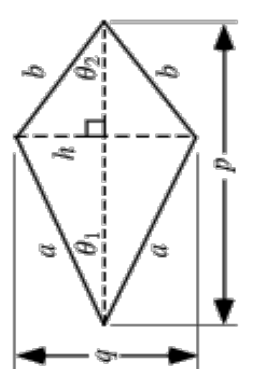

Figure 2. Kite 

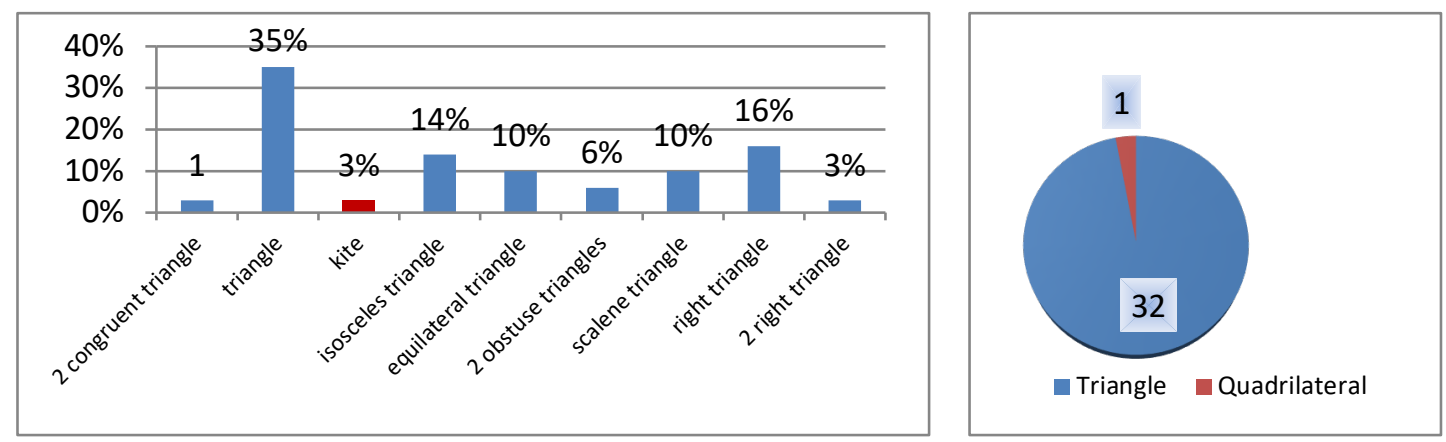

Graph 1. The first answer to question number 1

The tendency to classify the plane as a triangle still occurred for the second and third answer. In the second answer, the isosceles triangle is the majority of students' choices ( 7 students) while in the third answer, the equilateral triangle is chosen by nine students. The answer started to change in the fourth answer. Sixteen students stated that it was quadrilateral, and three students classified it as a kite. In the fifth answer, 4 of 16 students who classified the plane as quadrilateral turned into kites.

In general, for problem number 2, the students' responses were not much different from number 1 . Nineteen students still classified the plane as a triangle. However, the provided figures made some students finally decided to classify it as a quadrilateral, thus choosing a kite, from 4 to 11 students. Students' answers to question number two can be seen in Graph 2.
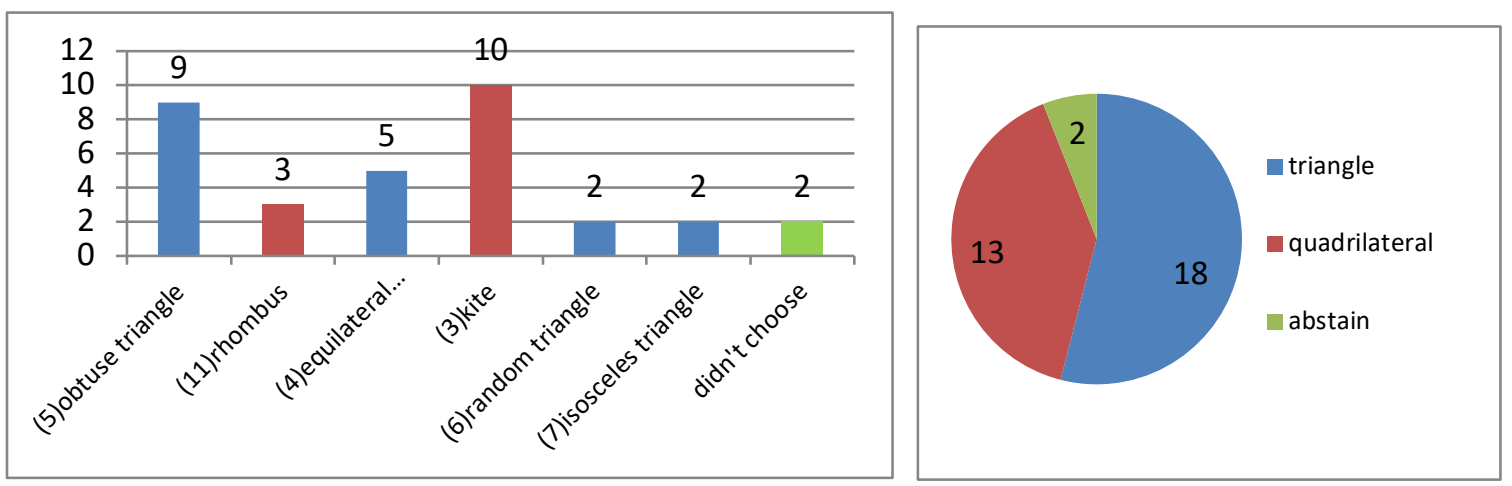

Graph 2. Students' answers to question number 2

Ten out of 33 students managed to identify the concave plane as a kite. Of the ten students, we found two types of answers: the students who guessed at the beginning that it was a kite and some students who did after the first guess. Each student from these two categories was chosen on the basis of a unique and interesting explanation that showed an indication of differences in thinking processes. For instance, one student reasoned that it was a kite because of having equal sides. It shows he saw the visible property of the plane. Meanwhile, another student explained that if the sides are pulled, then it will be a kite. This reveals her imagination on the given concave plane. Furthermore, a non-structured clinical interview was administered to explore the thinking processes of two subjects (S1 dan S2) who had different types of answers.

In the following section, we describe how the thinking process of the two subjects based on their works on the test and non-structured interviews. The description is divided into three parts, referring to three indicators of thinking processes by Suryabrata (2002): establish a definition, make opinions, and draw conclusions. 


\section{Thinking Process of S1}

In forming definition, S1 did three things. Firstly, S1 identified the properties of the concave plane and then looked for a plane which has similar properties. In the initial stage, S1 was able to see that the plane had four sides. It is consistent with the subjects' written answer (Figure 3). In the interview, S1 clarified what he means as has equal sides is two adjacent pairs of sides have equal length. Furthermore, S1 was able to identify that the concave plane has two acute angles. S1 also looked for a similar object as the concave plane, namely paragliding. In addition, he ignored the properties of a kite that did not belong to a concave plane. S1 said that the kite had two diagonals that intersect perpendicularly. Although the subject could not show these characteristics in the concave plane, he ignored this and still chose the kite as the first guess. On the second question, after initially drawing plane number 3 (Figure 4) S1 answered kite. It shows that $\mathrm{S} 1$ is easier to grasp something visible.

\section{Jawaban 1:}

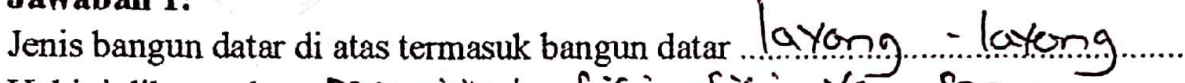

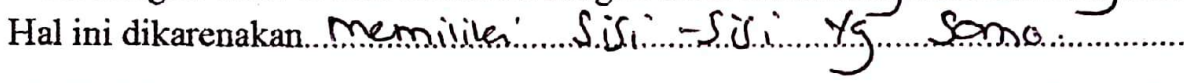

Figure 3. S1's answer to question number one

2. Diantara bangun datar di bawah ini, manakah yang paling mirip dengan bangun datar pada nomor 1 ? Berikan penjelasan dengan memilih sufat kedua bangun tersebut!
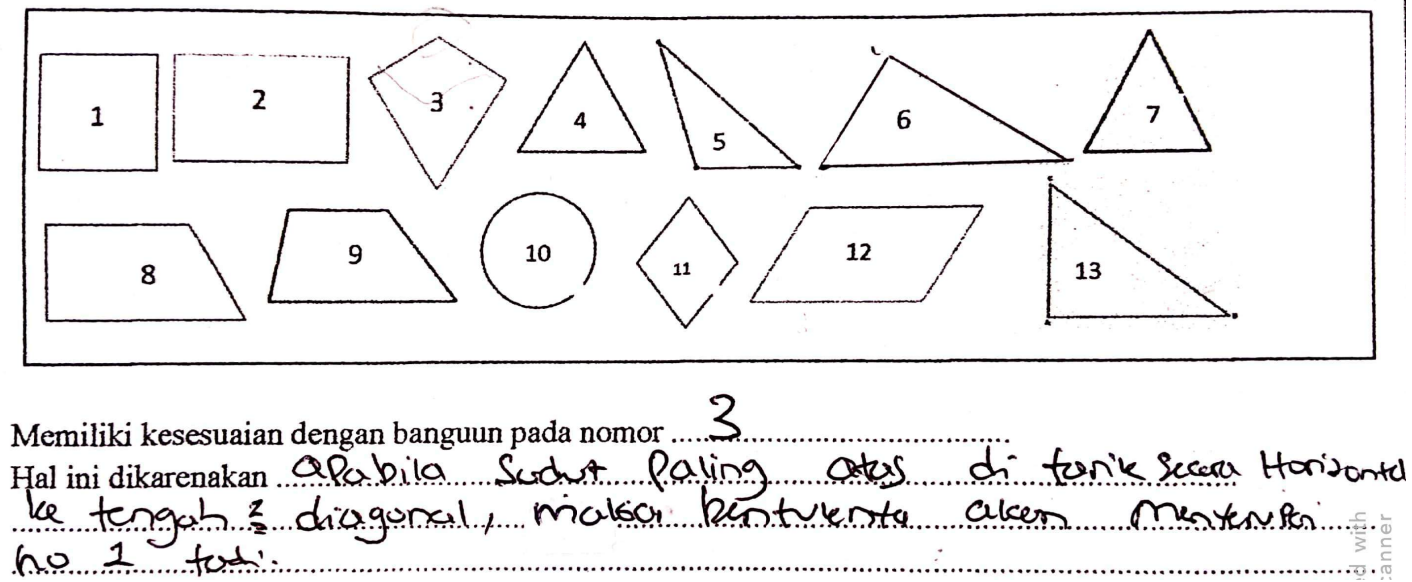

Figure 4. S1's answer to question number two

In making opinion, $\mathrm{S} 1$ gave several opinions which strengthened his reason for choosing a kite. He expressed positive opinions (affirmative), such as the characteristics of the sides that both had two pairs of sides with the same length and the characteristics of the angles where both planes had the same pair of angles. Furthermore, S1 also gave a negative opinion (negation), that is when he was not considering the plane on the test as a rectangle even though it also had two pairs of equal sides. The following interview excerpts show that S1 chose kites over rectangles.

\section{"The rectangle has four equal angles, but the kite has two equal angles, and the others} are different. Similar to the figure in the first question."

S1 also provided an opinion of modality (probability). It was evidenced through his assumption conveyed during the interview that a plane in the question had the same smoothness as the kite and had similarities with paragliding, so it is possible that the plane is a kite. 
The series of opinions ultimately strengthens S1 in concluding. From the interview process, S1 firstly identified the properties of the concave plane on the problem then looked for some planes considered to have the same properties or similar shapes. After S1 was able to prove or show the same properties, he then drew a conclusion on the type of plane. Thus, S1 drew conclusions inductively since he collected some facts and then gave a final conclusion.

\section{Thinking Process of S2}

$\mathrm{S} 2$ differs from $\mathrm{S} 1$ in identifying the concave plane. The answers given by $\mathrm{S} 2$ can be seen in Figure 5.

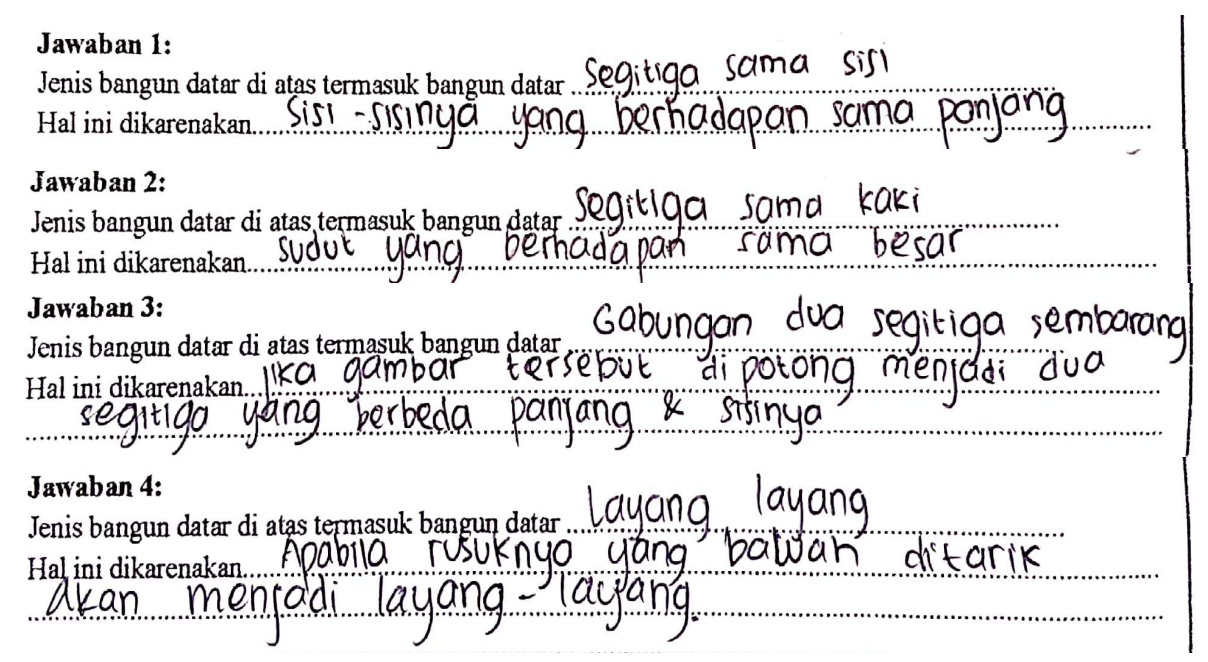

Figure 5. S2's answers to question number one

In the first to third answers, S2 considered the concave plane was a triangle referring to the properties it has. In the first answer, the reason is that two adjacent sides are equal, so the subject answered the equilateral triangle. In the second answer, S2 chose isosceles triangle because the concave plane had two equal angles. In contrast, in the third and fourth answers, the subject manipulated the plane in the problem and used her imagination to find similarities between the manipulated plane and the plane in the problem. In the third answer, S2 manipulated the concave plane by imagining a vertical line in the middle or symmetry axis. Thus it was divided into two scalene triangles. Another way of manipulation used by the subject in the fourth answer was by pulling down a pair of the adjacent side that forms an obtuse angle so that it resembles the shape of a kite. On question number 2, both subjects' answers were similar (Figure 6). However, S2 used her imagination to get the answer- did not need to draw as S1 did.

Referring to S2's works on question number one, the subject believed that the plane was a triangle. However, a different answer was given by S2 when answering question number 2. She preferred a kite as a plane which has the same characteristics as the concave plane. Based on the analysis of S2's written answers, it indicated distinct thinking processes as follows.

In establishing a definition, S2 assumed that two planes are alike if they have the same properties. It is drawn from the first to fourth answers (Figure 4) and the results of the interview. For example, on question number one, she answered equilateral triangles just by looking at one similar property; namely, two corresponding sides are equal without noticing the other two sides. Another example is that when she guessed the concave plane as an isosceles triangle by only pointing to one property: two equal angles without seeing the other two angles. This means, in the sense of the subject, planes will be of the same type if they have one property in common 
even though the other properties are not. Not only considering one property in common, but also one possible similar property which results from manipulation. For instance, S2 had a scalene triangle and a kite which have the same properties with the concave plane if it is divided into two parts or if it is pulled two sides away from the other two sides.

2. Diantara bangun datar di bawah ini, manakah yang paling mirip dengan bangun datar pada nomor 1 ? Berikan penjelasan dengan memilih sufat kedua bangun tersebut!

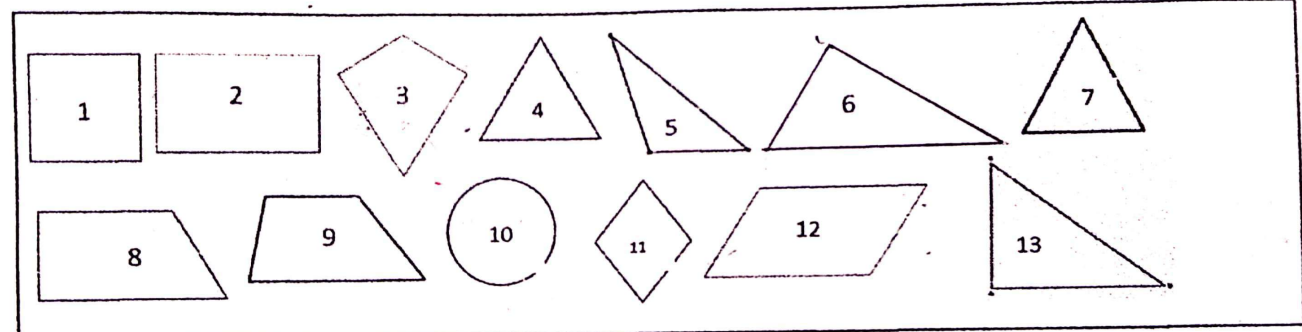

Memiliki kesesuaian dengan banguun pada nomor ...3

Hal ini dikarenakan jika sisi layang- ay ang y. atas di jorokkan

ke dalam akan membentuk nomor I dan sisrnya uga sama seperti yang nomor I.

Figure 6. S2's answer to question number two

In making opinion, S2 tended to give a positive opinion. It is an opinion that justifies or affirm something. For example, when she saw one pair of equal sides, one pair of equal angles, and mentioned having one folding symmetry in the interview session. Also, S2 had negative opinion found in the interview. It is an opinion that negates something. For instance, when she succeeded in recalling the property of the triangle, therefore, realizing that the first to third answers in question number one were wrong as in the following transcript.

$\begin{array}{lll}R & : \text { What are the properties of a triangle you know? } \\ S 2 & : \text {... (not answering) } \\ R & : \text { From its sides? } \\ S 2 & : \text { It has three } \\ R & : \text { How many sides this plane has? (Pointing to the concave plane } \\ & \quad \text { in the problem) } \\ S 2 & : \text { Two (pointing to the left and right side) } \\ R & : \text { Is it not a side? (pointing to two sides underneath) } \\ S 2 & : \text { Ohh yes, it has four. }\end{array}$

In the transcript, it appears that S2 realized that there were four sides, then it is not a triangle due to a negative opinion: the number of sides that were not equal to the number of sides of the triangle. She ultimately considered that a plane in the problem was not a triangle after asking the question about two sides which she was not aware of before. The truth that S2 got was a plane with four sides which were then called a quadrilateral. Besides giving a positive and negative opinion, S2 also gave an opinion of modality. The opinion was conveyed by the subject in the third and fourth answers when answering question number one. S2 imagined and estimated that the plane could resemble a triangle if the plane on the problem was divided into two equally in the middle. She also imagined that if the two lower sides were pulled down, the plane on the 
problem would resemble a kite. In providing the third and fourth guess, S2 only utilized her imagination without drawing as S1 did.

Referring to the formation of definition and opinion, S2 then drew conclusions in an analogous way. It is evident from the way she identified the plane in the problem by paying attention to the concepts he discovered so as to assume that the plane has the same properties as the kite. At first, S2 confidently made a conclusion when finding one similarity of property and did not think about others. However, after she drew a conclusion and then found dissimilarity with the property of the plane, she immediately drew a different conclusion. And so on until S2 really found a plane with the same property without the contradicted property between the plane as his conclusion and the plane in the problem. From this process, S2 collected many facts and concepts and then with her knowledge about the properties of a kite, she managed to give the correct conclusion.

Based on the description of the thinking processes of the two subjects, both have different thinking styles. S1 is more inclined to have a Sequential Concrete while S2 has a Random Abstract. It is consistent with the results of the questionnaire of the two subjects which can be seen in Figure 5. S1 had a score of 40 for sequential concrete (SK), 28 for sequential random (SA), 36 for random abstract (AA), and 16 for random concrete (AK). S2 had a score of 46 for random abstract, 12 for random concrete, 20 for sequential concrete, and 42 for sequential random.

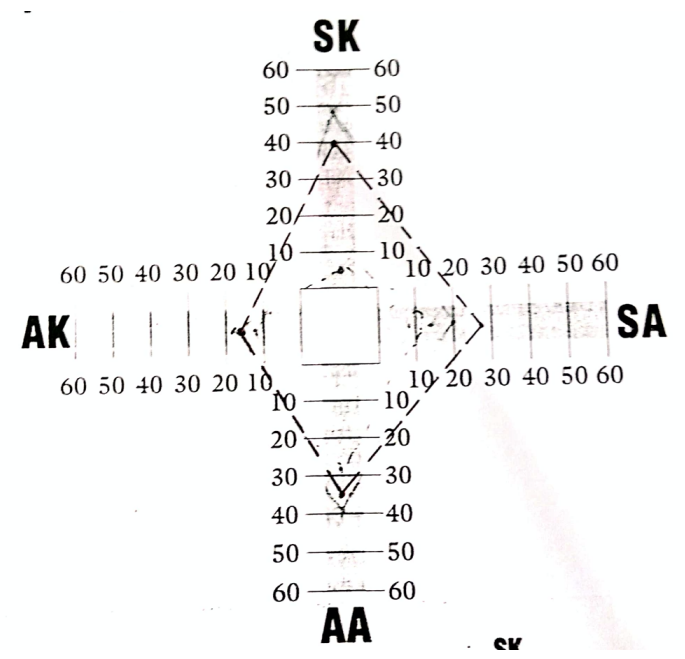

S1: Sequential Concrete

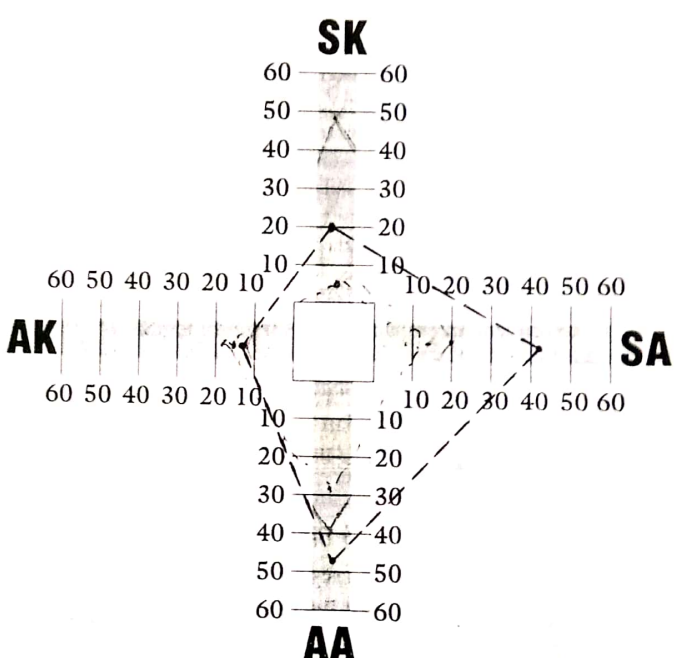

S2: Random Abstract

Figure 5. The results of thinking style questionnaires for S1 and S2

The different thinking process of the two thinking styles can be summarized in Table 2 and Table 3. 
Table 2. Matrix of thinking processes by Sequential Concrete subject

\begin{tabular}{ll}
\hline $\begin{array}{c}\text { Thinking processes and } \\
\text { indicators } \\
\text { (Suryabrata, 2002) }\end{array}$ & \multicolumn{1}{c}{$\begin{array}{c}\text { Thinking styles and indicators } \\
\text { of Sequential Concrete Subject } \\
\text { (Gregorc, 1982) }\end{array}$} \\
\hline $\begin{array}{l}\text { Establishing definition } \\
\text { Analyzing characteristics }\end{array}$ & $\begin{array}{l}\text { The subject: regularly analyzed concave plane through realistic } \\
\text { objects, analysed the sides and angles of the planes and compared } \\
\text { the concave plane with paragliding. } \\
\text { The subject compared the properties of the plane in the problem } \\
\text { with the object that has been seen: paragliding }\end{array}$ \\
Comparing characteristics & $\begin{array}{l}\text { The subject ignored/abstracted the difference of properties that are } \\
\text { not directly visible: the perpendicular diagonal. }\end{array}$ \\
Abstracting & $\begin{array}{l}\text { The subject: paid more attention to reality and gave positive } \\
\text { opinions when showing the similar properties of the kite and the } \\
\text { concave plane. } \\
\text { The subject managed to examine something in detail; it is evident } \\
\text { Giving a positive opinion }\end{array}$ \\
when he gave a negative opinion while proving that a rectangle is \\
not a plane that has similarities to the concave plane
\end{tabular}

Table 3. Matrix of thinking process by Random Abstract subject

\begin{tabular}{cc}
\hline $\begin{array}{c}\text { Thinking processes and } \\
\text { indicators }\end{array}$ & $\begin{array}{c}\text { Thinking styles and indicators } \\
\text { of Random Abstract Subject } \\
\text { (Guryabrata, 2002) }\end{array}$ \\
\hline
\end{tabular}

Establishing definition

Analyzing characteristics

Comparing characteristics

No abstraction

\section{Making opinion}

Giving a positive opinion
The subject: analyzed the characteristics by only looking at one characteristic in common. Thus, the subject tends to his own heart when analyzing.

The subject identified the concave plane by manipulating it and with his imagination identified the properties of the plane as a result of his manipulation. Thus, she managed to classify the plane as a kite.

No indications of abstraction

The subject: was able to absorb the ideas and visible impressions and provided a positive opinion by capturing an impression about the acute of the plane, two equal sides, and two equal angles. 


\begin{tabular}{ll}
\hline $\begin{array}{c}\text { Thinking processes and } \\
\text { indicators } \\
\text { (Suryabrata, 2002) }\end{array}$ & \multicolumn{1}{c}{$\begin{array}{c}\text { Thinking styles and indicators } \\
\text { of Random Abstract Subject } \\
\text { (Gregorc, 1982) }\end{array}$} \\
\hline Giving a negative opinion & $\begin{array}{l}\text { As a result of the nature of the subject which is less organized and } \\
\text { tends to be arbitrary in its own thinking, the subject gave a } \\
\text { negative opinion when realizing that the plane on the problem is } \\
\text { not a triangle. } \\
\text { The subject: had a good imagination, provided the opinion of } \\
\text { modality (possibility) when arguing that the plane has a similarity } \\
\text { to a kite when two lower sides are drawn downward, had } \\
\text { difficulties to think in limited circumstances, and lacked calmness } \\
\text { in the analysis. The test in identifying a concave plane was done } \\
\text { in class and limited by time thus the subject found it difficult to } \\
\text { develop his mind, and in the end, she only gave answers } \\
\text { according to his desire without being analyzed deeply. }\end{array}$ \\
modality & $\begin{array}{l}\text { The subject: often provided conclusions in a hurry, was less } \\
\text { organized, and looked at the information thoroughly, and then } \\
\text { drew conclusion analogically. }\end{array}$ \\
\hline $\begin{array}{l}\text { Drawing conclusion } \\
\text { Drawing conclusions } \\
\text { analogically }\end{array}$ &
\end{tabular}

Table 2 shows that the subject with a Sequential Concrete thinking style has several characteristics in identifying a concave plane: examining something in detail, paying more attention to existing realities, not imaginative, holding on to reality, and drawing conclusions deductively. The subject with Random Abstract thinking style (Table 3) shows the difficulty of thinking in a restricted situation, tends to think at will or according to his own imagination, has a good imagination, able to absorb ideas and visible impressions, has less organized way of thinking, able to see abstract things after capturing an overall impression of it (holistically), and provide conclusions analogically.

Two thinking styles found in the present study, Random Abstract and Sequential Concrete, have a distinct process of thinking in establishing a definition, making the opininion, and drawing the conclusion. Similar cases were also found by Djadir et al. (2018) where students with Sequential Concrete tend to organize facts, obtain systematically, and present information in a whole range of things, while Random Abstract students tend to have trial and error in solving problems. However, these differences do not preclude success in constructing mathematics knowledge. Indeed, Manaig, Yazon, \& Tesoro (2015) found that there was no significant relationship between thinking styles with academic achievement. Thinking style is not a predictor that can determine the success or failure of one's thinking process. In addition, the present study reveals that students' thinking style tend to be consistent at each stage of their thinking process. For example, the student with Sequential Concrete maintains his regular way of thinking not only in the establishment of definition but also in making opinion and drawing a conclusion. Likewise, Random Abstract student shows random thinking in three stages of the thinking process.

\section{Conclusion}

This study found two different thinking styles from students who managed to identify a concave plane as a kite: Sequential Concrete and Random Abstract. Students with different thinking styles have different thinking processes in establishing a definition, making the opinion, 
and drawing the conclusion. The differences in each stage of thinking process respectively lay on sequentially or randomly of analyzing mathematical facts, the ability to use imagination, and the way of drawing conclusion inductively or analogically. Despite these distinctions, students with different thinking styles in their thinking process are still able to construct mathematical ideas. The present study only found two thinking styles which refer to Gregorc model and yield important descriptions on how the students successfully identified the concave plane as a kite. Thus, the other thinking styles such as Sequential Abstract and Random Concrete are not known yet whether or not they have different thinking process which affects the construction of mathematical knowledge. Thus, further studies are required to answer this question.

\section{References}

Aydogdu, M.Z., \& Kesan, C. (2014). A research on geometry problem solving strategies used by elementary mathematics teacher candidates. Journal of Educational and Instructional Studies in the World, 4(1), 53-62.

Biber, Ç., Tuna, A., \& Korkmaz, S. (2013). The mistakes and the misconceptions of the eighth grade students on the subject of angles. European Journal of Science and Mathematics Education, 1(2), 5059.

Ministry of Education and Culture (MoEC). (2016). Peraturan Menteri Pendidikan dan Kebudayaan nomor 21 tahun 2016 tentang Standar Isi Pendidikan Dasar dan Menengah. Jakarta: Kementerian Pendidikan dan Kebudayaan.

Creswell, J.W., \& Creswell, J.D. (2014). Research design: Qualitative, quantitative, and mixed methods approaches ( $4^{\text {th }}$ edition). Sage publications.

DePorter, B., \& Hernacki, M. (2016). Quantum Learning: Membiasakan belajar nyaman dan menyenangkan (A. Abdurrahman, Trans.). Bandung: Penerbit Kaifa.

Djadir, Upu, H., \& Sulfianti, A. (2018). The profile of students' mathematical problem solving on the topic of two-variable linear equation systems based on thinking styles. Journal of Physics: Conference Series, 1028(1), 012164. IOP Publishing.

Gregorc, A. F. (1982). An adult's guide to style. Maynard, MA: Gabriel Systems.

Gunhan, B., Turgut, M., Yilmaz. (2009). Spatial ability of a mathematics teacher: The case of Oya. IBSU Scientific Journal 2009, 3(1), 151-158.

Lussier, R. N., \& Hendon, J. R. (2017). Human resource management: Function, applications, and skill development. London: Sage publications.

Manaig, K. A., Yazon, A. D., Tesoro, J. F. (2015). Thinking style and academic achievement of selected first year teacher education students at the Laguna State Polytechnic University Los Baños Campus. Proceeding of the $3^{\text {rd }}$ Global Summit Education GSE 2015, Kuala Lumpur, Malaysia. Retrieved from https://worldconferences.net/proceedings/gse2015

Masfingatin, T. (2014). Proses berpikir siswa sekolah menengah pertama dalam menyelesaikan masalah bangun ruang sisi datar berdasarkan teori Van Hiele. JIPM (Jurnal Ilmiah Pendidikan Matematika), 3(1). Doi: $10.25273 /$ jipm.v3i1.496

Misnasanti \& Mahmudi, A. (2018). Van Hiele thinking level and geometry visual skill towards field dependent-independent students in junior high school. Journal of Physics: Conference Series, 1097(1). Doi: 10.1088/1742-6596/1097/1/012133

Mutia, M. (2017). Analisis kesulitan siswa SMP dalam memahami konsep kubus balok dan alternatif pemecahannya. Beta: Jurnal Tadris Matematika, 10(1), 83-102. Doi: 10.20414/betajtm.v10i1.107

Mustaqim, \& Wahib, A. (2010). Psikologi Pendidikan. Jakarta: PT Rineka Cipta.

Myers, B.E., \& Dyer, J.E. (2006). The influence of student learning style on critical thinking skill. Journal of Agricultural Education, 47(1), 43-52. Doi: 10.5032/jae.2006.01043

Purwanto, N. (2013). Psikologi Pendidikan. Bandung: PT Remaja Rosdakrya Offset.

Özerem, A. (2012). Misconceptions in geometry and suggested solutions for seventh grade students. Procedia-Social and Behavioral Sciences, 55, 720-729. Doi: 10.1016/j.sbspro.2012.09.557 
Ramadhan, F. (2017). Proses berpikir siswa SMP dalam pemecahan masalah matematika ditinjau dari gaya kognitif reflektif dan impulsif (Magister thesis). Aceh: Universitas Syiah Kuala.

Sahatcija, R., Ora, A., Ferhataj, A. (2017). The impact of the thinking style on teaching methods and academic achievement. Europan Scientific Journal, 13 (34), 1857-7881. Doi: 10.19044/esj.2017.v13n34p16

Santrock, J.W. (2007). Psiklogi Pendidikan. Jakarta: Kencana.

Setyawan, D. (2017). Exploration of students knowledge construction process on geometry througt random thinking style and spatial ability of mental rotation level. Jurnal Daya Matematis, 5(2), 124 135. Doi: $10.26858 /$ jds.v5i2.3348

Suryabrata, S. (2002). Psikologi Pendidikan. Jakarta: PT Grafindo Perkasa.

Suryadinata, N., \& Farida, N. (2016). Analisis proses berpikir anak berkebutuhan khusus (ABK) dalam menyelesaikan masalah matematika di SMP Inklusi Kota Metro (Studi kasus pada siswa tunagrahita ringan). AKSIOMA: Jurnal Program Studi Pendidikan Matematika,5(1), 94-104. Doi: 10.24127/ajpm.v5i1.470

TIMSS. (2015). TIMSS 2015 International Results in Mathematics. Retrieved from http://timss2015.org/home/internationaldatabase/2015

Yanti, A. P., \& Syazali, M. (2016). Analisis proses berpikir siswa dalam memecahkan masalah matematika berdasarkan langkah-langkah Bransford dan Stein ditinjau dari Adversity Quotient. AlJabar: Jurnal Pendidikan Matematika, 7(1), 63-74. Doi: 10.24042/ajpm.v7i1.132

Zakir, M. (2015). Description of logical reasoning in solving mathematics problemss based on students' thinking style of students at SMP N 2 Pinrang. Jurnal Daya Matematis, 3(2), 152. Doi: 10.26858 /jds.v3i2.3229

Zazkis, R., \& Hazzan, O. (1998). Interviewing in mathematics education research: Choosing the questions. The Journal of Mathematical Behavior, 17(4), 429-439. 